\title{
COMPARATIVE STUDIES ON SOME HONEYBEE ACTIVITIES AT ELSHARKIA GOVERNORATE
}

\author{
R. E. Sanad ${ }^{(1)}$, F. E. Elsantil( ${ }^{(2)}$, H. E. Elsharkawy ${ }^{(2)}$ and R.T. Ibrahim ${ }^{(1)}$ \\ (1) Apiculture Department, Plant Protection Res. Ins. \\ (2) Faculty of Technology and Development, Zagazig University.
}

Received: Jan. 22 , 2018

Accepted: Feb. 10,2018

\begin{abstract}
The activities of honeybee colonies were recorded along two successive years 2014 and 2015 at three localities of Elsharkia Governorate. Statistical analysis of the obtained data revealed that there were no significant differences in the monthly average area of sealed brood honey bee along the years of study, while there were significant differences in the monthly average area of sealed brood honey bee in inch $^{2}$ / colony among the year months, where the highest mean area of sealed brood honey bee per colony were recorded at July and August recording 220.2 and 208.9 inch $^{2}$ at 2014 year, and the highest mean area of sealed brood honey bee per colony were recorded at July and August recording 220.2 and 208.9 inch $^{2}$ at 2015 year. As for the average weights of pollen grains $(g) /$ trap/month at the three localities of Sharkia governorate along 2014 and 2015 months, the highest mean average weights of pollen grains (g/trap/month) were recorded at July and August months recording 203.7 and 219.9 (g/trap/month) at 2014 , and the highest mean average weights of pollen grains (g/trap/month) were recorded at July and August months recording 207.8 and 224.0 (g/trap/month) at 2015. The highest weights of honey were recorded at clover season recording $15.83 \mathrm{~kg} /$ colony at citrus season (LSD 5\% = 2.03), followed by cotton and citrus seasons giving 10.42 and $9.61 \mathrm{~kg} /$ colony without significant differences at 2014 months, and the highest mean average weights of pollen grains (g/trap/month) were recorded at July and August months recording 203.7 and 219.9 (g/trap/month) at 2015 months.
\end{abstract}

Key words: Apis mellifera, foraging, sealed brood, pollen grains, honey

\section{INTRODUCTION}

Strains of honeybees differ in morphometrical and physiological characteristics, and these differences affect the production aspects of their products, Shawer (1980) Polishchuk, (1984) and Abou El-Enain (2000) Bankova, et al., (2007). Honeybees, Apis mellifera $\mathrm{L}$ produce different products which use mainly in food and others in different purposes i.e., therapeutic or in the apitherapy science. The most spread colonies of honeybee in Egypt are Carniolan hybrids. The large needs of different honeybee products propolis, pollen grain, need further comparative studies on bee hybrids. There are a few studies on the Honeybee Apis mellifera $\mathrm{L}$ products which use mainly in food and others in different purposes i.e., therapeutic or in the apitherapy science .

As for honey production, Farrar (1968) revealed that there were wide variations in production efficiency between strains of bees within three common races: Italian, Caucasian and Carniolan than between them. Sugden and Furgala (1982) stated that the variation of honey production between colonies in the same apiary may due to variation of genetic makeup of the colony. Hussein (1983) in Assuit region, Upper Egypt, found that the gain weights of the tested colonies were $36.8,31.2,27.8,14.1,6.5$ and $4.3 \mathrm{~kg}$. During July, August, May, June, 
September and March. Rashad, et al. (1979) mentioned that, four major pollen sources were observed in Giza region, Egypt. The total amounts of pollen trapped from four honey bee colonies averaged 401.4, 257.9, 113.3 and 29.0 grams/colony related to Egyptian clover, maize, wild mustard and broad bean, respectively. Richard, et al. (1986) mentioned that honeybees (Apis mellifera) from a line which had been selected for high pollen-hoarding behaviour (HPH) hoarded more pollen than bees from a low pollen-hoarding line (LPH) when were kept in observation colonies with known amounts of brood. In Brazil, Malaspina and Patenate (1995) reported that Africanized and Italian bees being more efficient than Carniolan bees. In addition, Funari, et al. (2003) studied the effects of pollen collection on colony development and its activities of Apis mellifera. Moreover, in Egypt, Mansour et al. (2008) conducted a comparative study on some activities and products between hybrids of Carniolan and Italian honeybee colonies.

The aim of this study is to compare some characters and products of honey bee Carniolan hybrids at three localities of Elsharkia Governorate.

\section{MATERIALS AND METHODS}

The field experiments were carried out in private apiaries located at Zagazig city, Diarb Negm city, Belbis city of Elsharkia Governorate.

\section{Honeybee colonies:}

All private apiaries of the honeybee colonies , Apis mellifera at El Elsharkia Governorate were chosen for this study was Carniolan hybrids. Twenty one honeybee colonies from each city were selected which were similar in its strength and population.

\section{Experimental design :} Chosen colonies were arranged as completely randomized block design representing twenty one honeybee colonies of each locality.

\section{Procedure of work :}

Chosen colonies were observed and examined monthly during the period from January 2014 till December 2015 where some characters and products were recorded.

\section{4- Observed activities:}

4-1- Brood rearing activity:

The previous colonies were used for this test to determine the brood rearing activity as effected by different localities of Elsharkia Governorate from January 2014 till December 2015. For estimating the brood rearing activity, sealed brood areas of workers and drones were measured for each colony in square inches at 12 days intervals (Fresnay, 1962).

\section{4-2- Pollen grains :}

Pollen traps were placed at the entrance of colonies. The traps were similar to the types used by Dimou and Thrasyvoulou (2007). The traps were emptied every 3 days and the contents were weighed and recorded.

The colonies were compensated by pollen substitutes.

\section{4-3- Honey bee yield :}

Honey was collected three times, clover season, citrus season and cotton season, weighted and recorded as $\mathbf{k g} /$ colony according to Shawer, 1987 , Mansour et al. (2008).

\section{Statistical analysis of the data:}

Collected data were subjected to statistical analysis of variance (ANOVA) at $5 \%$ probability, and the measurements were separated using Duncan's Multiple Range Test (DMRT) through CoStat software program (Version 6.400). CoStat version 6.400 Copyright (c) 1998-2008 
Cohort Software. 798 Lighthouse Ave. PMB 320, Monterey, CA, 93940, USA.

\section{RESULTS AND DISCUSSION}

The obtained results in Table (1) show the monthly average area $\left(\right.$ inch $^{2}$ ) / colony of sealed brood honey bee at 3 localities of Sharkia governorate along 2014 and 2015 months.

Statistical analysis of the obtained data revealed that there were no significant differences in the monthly average area of sealed brood honey bee in inch $^{2} /$ colony, where it was 129.6 , 137.4 , 145.8 inch $^{2}$ / colony, for Zagazig, Diarb Nigm, Belbis localities, respectively, while there were significant differences in the monthly average area of sealed brood honey bee in inch $^{2}$ / colony among the year months, where the highest mean area of sealed brood honey bee per colony were recorded at July and August recording 220.2 and 208.9 inch $^{2}$ (LSD 5\% = 15), while the least mean area of sealed brood honey bee per colony were recorded at December and January recording 42.5 and 48.4 inch $^{2}$ (LSD 5\% = 15) .

The obtained results in Table (2) show the monthly average area $\left(\right.$ inch $\left.^{2}\right) /$ colony of sealed brood honey bee at 3 localities of Sharkia governorate along 2015 months.

Table (1): Monthly average area (inch ${ }^{2}$ ) / colony of sealed brood honey bee at 3 localities of Sharkia governorate along 2014 months

\begin{tabular}{|c|c|c|c|c|c|}
\hline \multirow{2}{*}{$\begin{array}{c}2014 \\
\text { Months }\end{array}$} & \multicolumn{3}{|c|}{$\begin{array}{c}\text { average area }\left(\text { inch }^{2}\right) / \text { colony) of sealed brood } \\
\text { honey bee }\end{array}$} & \multirow{2}{*}{ Total } & \multirow{2}{*}{ Mean } \\
\hline & Zagazig & Diarb Nigm & Belbis & & \\
\hline January & 46.4 & 48.6 & 50.2 & 145.2 & $48.4 \mathrm{~h}$ \\
\hline February & 74.8 & 78.2 & 80.6 & 233.6 & $77.9 \mathrm{~g}$ \\
\hline March & 117.0 & 118.6 & 122.8 & 358.4 & $119.5 f$ \\
\hline April & 138.4 & 143.4 & 150.2 & 432 & $144.0 \mathrm{e}$ \\
\hline May & 161.0 & 168.8 & 176.6 & 506.4 & $168.8 d$ \\
\hline June & 188.4 & 197.2 & 201.8 & 587.4 & $195.8 b$ \\
\hline July & 198.2 & 221.6 & 240.8 & 660.6 & $220.2 a$ \\
\hline August & 195.0 & 210.4 & 221.2 & 626.6 & 208.9ab \\
\hline September & 164.6 & 172.8 & 200.4 & 537.8 & $179.3 \mathrm{c}$ \\
\hline October & 150.0 & 158.4 & 168.8 & 477.2 & $159.1 d$ \\
\hline November & 80.6 & 88.0 & 92.0 & 260.6 & $86.9 \mathrm{~g}$ \\
\hline December & 40.4 & 42.2 & 44.8 & 127.4 & $42.5 h$ \\
\hline Total & 1554.8 & 1648.2 & 1750.0 & 4953.0 & 1651.0 \\
\hline Mean & $129.6 \mathrm{~ns}$ & 137.4 ns & $145.8 \mathrm{~ns}$ & 412.8 & 137.6 \\
\hline L.S.D $5 \%$ & & 25.6 & & & 15.0 \\
\hline
\end{tabular}

Means in column or row followed by different letter(s) are significantly different at $5 \%$ level 
R. E. Sanad, et al.,

Table (2): Monthly average area (inch ${ }^{2}$ ) / colony of sealed brood honey bee at 3 localities of Sharkia governorate along 2015 months

\begin{tabular}{|c|c|c|c|c|c|}
\hline \multirow{2}{*}{$\begin{array}{l}2015 \\
\text { Months }\end{array}$} & \multicolumn{3}{|c|}{$\begin{array}{c}\text { average area }\left(\text { inch }^{2}\right) / \text { colony) of sealed brood } \\
\text { honey bee }\end{array}$} & \multirow{2}{*}{ Total } & \multirow{2}{*}{ Mean } \\
\hline & Zagazig & Diarb Nigm & Belbis & & \\
\hline January & 47.2 & 49.4 & 50.4 & 147 & $49 g$ \\
\hline February & 75.8 & 79.6 & 81.4 & 236.8 & $78.9 f$ \\
\hline March & 118.2 & 121.4 & 123.8 & 363.4 & $121.1 \mathrm{e}$ \\
\hline April & 141.0 & 145.6 & 148.4 & 435 & $145.0 d$ \\
\hline May & 163.8 & 171.8 & 177.2 & 512.8 & $170.9 \mathrm{c}$ \\
\hline June & 191.6 & 198.4 & 202.8 & 592.8 & $197.6 \mathrm{~b}$ \\
\hline July & 203.6 & 227.8 & 236.2 & 667.6 & $222.5 a$ \\
\hline August & 198.6 & 216.8 & 219.6 & 635 & 211.7ab \\
\hline September & 166.8 & 175.6 & 196.2 & 538.6 & $179.5 \mathrm{c}$ \\
\hline October & 153.8 & 164.2 & 169.4 & 487.4 & $162.5 \mathrm{c}$ \\
\hline November & 78.4 & 86.6 & 89.2 & 254.2 & $84.7 f$ \\
\hline December & 41.8 & 44.2 & 45.6 & 131.6 & $43.9 \mathrm{~g}$ \\
\hline Total & 1580.6 & 1681.4 & 1740.2 & 5002.2 & 1667.3 \\
\hline Mean & $131.7 \mathrm{~ns}$ & $140.1 \mathrm{~ns}$ & $145.0 \mathrm{~ns}$ & 416.8 & 138.9 \\
\hline L.S.D $5 \%$ & & 18.2 & & & 17.8 \\
\hline
\end{tabular}

Means in column or row followed by different letter(s) are significantly different at $5 \%$ level

Statistical analysis of the obtained data revealed that there were no significant differences in the monthly average area of sealed brood honey bee in inch $^{2} /$ colony, where it was 129.6 , 137.4 , 145.8 inch $^{2}$ / colony, for Zagazig, Diarb Nigm, Belbis localities, respectively, while there were significant differences in the monthly average area of sealed brood honey bee in inch $^{2}$ / colony among the year months, where the highest mean area of sealed brood honey bee per colony were recorded at July and August recording 220.2 and
208.9 inch $^{2}$ (LSD 5\% = 17.8), while the least mean area of sealed brood honey bee per colony were recorded at December and January recording 42.5 and 48.4 inch $^{2}$ (LSD 5\% = 17.8).

The obtained results in Table (3) show the monthly average weights of pollen grains (g) /trap/month at the three localities of Sharkia governorate along 2014 months.

Statistical analysis of the obtained data revealed that there were significant differences in the monthly average 
weights of pollen grains ( $\mathrm{g} / \mathrm{trap} / \mathrm{month})$, where it was $120.55,111.26,84.48$ $\mathrm{g} /$ trap/month , for Zagazig, Diarb Nigm, Belbis localities, respectively (LSD $5 \%=$ 6.5). In addition, there were significant differences in the monthly average weights of pollen grains $(g) /$ trap/month among the year months, where the highest mean average weights of pollen grains ( $\mathrm{g} / \mathrm{trap} / \mathrm{month})$ were recorded at July and August months recording 203.7 and 219.9 (g/trap/month) (LSD $5 \%=17.1)$
, while the least average weights of pollen grains (g) /trap/month were recorded from October to February months ranging from 35.4 to 51.2 (g/trap/month) (LSD 5\% $=17.1)$.

The obtained results in Table (4) show the monthly average weights of pollen grains (g) /trap/month at the three localities of Sharkia governorate along 2015 months.

Table (3): Monthly average weights of pollen grains (g)/trap/month collected by workers at three localities of Sharkia governorate along 2014 months

\begin{tabular}{|c|c|c|c|c|c|}
\hline \multirow{2}{*}{$\begin{array}{l}2014 \\
\text { Months }\end{array}$} & \multicolumn{3}{|c|}{$\begin{array}{l}\text { Ave. weights of pollen grains }(\mathrm{g}) / \text { trap/ } \\
\text { month }\end{array}$} & \multirow{2}{*}{ Total } & \multirow{2}{*}{ Mean } \\
\hline & Zagazig & Diarb Nigm & Belbis & & \\
\hline January & 47.1 & 42.1 & 30.1 & 119.3 & $39.8 e$ \\
\hline February & 56.2 & 51.4 & 24.8 & 132.4 & $44.1 \mathrm{e}$ \\
\hline March & 118.2 & 93.7 & 70.8 & 282.7 & $94.2 \mathrm{c}$ \\
\hline April & 119.2 & 97.1 & 73.8 & 290.1 & $96.7 d$ \\
\hline May & 150.7 & 138.7 & 115.1 & 404.5 & $134.8 \mathrm{c}$ \\
\hline June & 192.4 & 184.2 & 135.4 & 512 & $170.7 b$ \\
\hline July & 227.8 & 214.8 & 168.4 & 611 & 203.7a \\
\hline August & 237.5 & 228.1 & 194.0 & 659.6 & $219.9 a$ \\
\hline September & 138.1 & 132.5 & 121.3 & 391.9 & $130.6 \mathrm{c}$ \\
\hline October & 61.4 & 59.5 & 32.8 & 153.7 & $51.2 e$ \\
\hline November & 53.7 & 49.6 & 28.8 & 132.1 & $44.0 e$ \\
\hline December & 44.3 & 43.4 & 18.4 & 106.1 & $35.4 e$ \\
\hline Total & 1446.6 & 1335.1 & 1013.7 & 3795.4 & 1265.13 \\
\hline Mean & $120.55 \mathrm{a}$ & $111.26 \mathrm{~b}$ & $84.48 \mathrm{c}$ & 316.3 & 105.43 \\
\hline L.S.D ${ }_{5 \%}$ & & 6.5 & & & 17.1 \\
\hline
\end{tabular}

Means in column or row followed by different letter(s) are significantly different at $5 \%$ level 
R. E. Sanad, et al.,

Table (4): Monthly average weights of pollen grains (g)/trap/month collected by workers at three localities of Sharkia governorate along 2015 months

\begin{tabular}{|c|c|c|c|c|c|}
\hline \multirow{2}{*}{$\begin{array}{l}2015 \\
\text { Months }\end{array}$} & \multicolumn{3}{|c|}{$\begin{array}{l}\text { Ave. weights of pollen grains (g) } \\
\text { /trap/ month }\end{array}$} & \multirow{2}{*}{ Total } & \multirow{2}{*}{ Mean } \\
\hline & Zagazig & Diarb Nigm & Belbis & & \\
\hline January & 50.8 & 44.5 & 37.4 & 132.7 & $44.2 e$ \\
\hline February & 59.5 & 54.2 & 49.4 & 163.1 & $54.4 \mathrm{e}$ \\
\hline March & 123.0 & 98.9 & 82.5 & 304.4 & $101.5 d$ \\
\hline April & 125.1 & 103.2 & 91.0 & 319.3 & $106.4 d$ \\
\hline May & 155.9 & 141.1 & 120.8 & 417.8 & $139.3 \mathrm{c}$ \\
\hline June & 196.2 & 188.1 & 140.4 & 524.7 & $174.9 \mathrm{~b}$ \\
\hline July & 230.9 & 219.6 & 172.9 & 623.4 & $207.8 a$ \\
\hline August & 241.1 & 231.8 & 199.2 & 672.1 & $224.0 a$ \\
\hline September & 140.9 & 136.1 & 123.8 & 400.8 & $133.6 \mathrm{c}$ \\
\hline October & 65.6 & 62.1 & 37.5 & 165.2 & $55.1 \mathrm{e}$ \\
\hline November & 55.8 & 50.9 & 32.6 & 139.3 & $46.4 e$ \\
\hline December & 45.6 & 45.9 & 24.1 & 115.6 & $38.5 e$ \\
\hline Total & 1490.4 & 1376.4 & 1111.6 & 3978.4 & 1326.1 \\
\hline Mean & $124.2 a$ & $114.7 \mathrm{~b}$ & $92.6 \mathrm{c}$ & 331.5 & 110.5 \\
\hline L.S.D ${ }_{5 \%}$ & & 7.5 & & & 18.5 \\
\hline
\end{tabular}

Means in column or row followed by different letter(s) are significantly different at $5 \%$ level

Statistical analysis of the obtained data revealed that there were significant differences in the monthly average weights of pollen grains ( $g /$ trap/month), where it was 124.2, $114.7,92.6$ $\mathrm{g} /$ trap/month, for Zagazig, Diarb Nigm, Belbis localities, respectively (LSD $5 \%=$ 7.5). In addition, there were significant differences in the monthly average weights of pollen grains (g)/trap/month among the year months, where the highest mean average weights of pollen grains ( $g /$ trap/month) were recorded at
July and August months recording 207.8 and 224.0 (g/trap/month) (LSD 5\% = 18.5), while the least average weights of pollen grains (g) /trap/month were recorded from October to February months ranging from 38.5 to 55.0 ( $\mathrm{g} /$ trap/month) (LSD 5\% = 18.5) .

The obtained results in Table (5) show the annual average weight of honey $(\mathrm{kg} / 5$ colony) collected by workers at 3 localities of Sharkia governorate along 2014 months. 
Statistical analysis of the obtained data revealed that there were no significant differences in the average weights of honey (kg/colony/ year) collected by workers among the tested three localities, where it was 11.48 , $12.18,12.2 \mathrm{~kg} /$ colony / year at Zagazig, Diarb Nigm, Belbis localities, respectively (LSD $5 \%=1.0$ ), while it was significant differences in the seasonally average weights of honey (kg/colony/season ) at 2014 year. The highest weights of honey were recorded at clover season recording $15.83 \mathrm{~kg} \mathrm{/}$ colony at citrus season (LSD $5 \%=2.03$ ), followed by cotton and citrus seasons giving 10.42 and $9.61 \mathrm{~kg} \mathrm{/} \mathrm{colony}$ without significant differences (LSD $5 \%=$ 2.03).

The obtained results in Table (6) show the annual average weight of honey $(\mathrm{kg} / 5$ colony) collected by workers at 3 localities of Sharkia governorate along 2015 months.

Table (5): Annual average weight of honey( $\mathrm{kg} / 5$ colony) collected by workers at 3 localities of Sharkia governorate along 2014 seasons

\begin{tabular}{|l|c|c|c|c|l|}
\hline \multirow{2}{*}{ Seasons } & \multicolumn{2}{|c|}{ Ave. weights of honey (kg/ 5 colony) } & \multirow{2}{*}{ Total } & \multirow{2}{*}{ Mean } \\
\cline { 2 - 4 } & Zagazig & Diarb Nigm & Belbis & & \\
\hline Citrus & 8.5 & 9.65 & 10.7 & 28.85 & $9.61 \mathrm{~b}$ \\
\hline Clover & 15.15 & 16.75 & 15.6 & 47.5 & $15.83 \mathrm{a}$ \\
\hline Cotton & 10.8 & 10.15 & 10.3 & 31.25 & $10.42 \mathrm{~b}$ \\
\hline Total & 34.45 & 36.55 & 36.6 & 107.6 & 35.86 \\
\hline Mean & $11.48 \mathrm{~ns}$ & $12.18 \mathrm{~ns}$ & $12.2 \mathrm{~ns}$ & 35.86 & 11.95 \\
\hline L.S.D & & 1.0 & & & 2.03 \\
\hline
\end{tabular}

Means in column or row followed by different letter(s) are significantly different at $5 \%$ level

Table (6): Annual average weight of honey ( $\mathrm{kg} / 5$ colony) collected by workers at 3 localities of Sharkia governorate along 2015 seasons

\begin{tabular}{|l|c|c|c|c|c|}
\hline \multirow{2}{*}{ Seasons } & \multicolumn{2}{|l|}{ Ave. weights of honey( kg/5colony) } & \multirow{2}{*}{ Total } & \multirow{2}{*}{ Mean } \\
\cline { 2 - 4 } & Zagazig & Diarb Nigm & Belbis & & \\
\hline Citrus & 8.65 & 9.95 & 11.2 & 29.8 & $9.93 \mathrm{~b}$ \\
\hline Clover & 15.35 & 16.95 & 15.81 & 48.11 & $16.04 \mathrm{a}$ \\
\hline Cotton & 10.95 & 10.53 & 10.09 & 31.57 & $10.52 \mathrm{~b}$ \\
\hline Total & 34.95 & 37.43 & 37.1 & 109.48 & 36.49 \\
\hline Mean & $11.65 \mathrm{~ns}$ & $12.47 \mathrm{~ns}$ & $12.37 \mathrm{~ns}$ & 36.49 & 12.16 \\
\hline L.S.D & & 1.4 & & 1.98 \\
\hline
\end{tabular}

Means in column or row followed by different letter(s) are significantly different at $5 \%$ level 
Statistical analysis of the obtained data revealed that there were no significant differences in the average weights of honey (kg/colony/ year) collected by workers among the tested three localities, where it was $11.65,12.47$, $12.37 \mathrm{~kg} /$ colony / year at Zagazig, Diarb Nigm, Belbis localities, respectively (LSD $5 \%=1.4$ ), while it was significant differences in the seasonally average weights of honey (kg/colony/season) at 2015 year. The highest weights of honey were recorded at clover season recording $16.04 \mathrm{~kg} /$ colony at citrus season (LSD $5 \%=1.98$ ), followed by cotton and citrus seasons giving 10.52 and $9.93 \mathrm{~kg} /$ colony without significant differences (LSD $5 \%=$ 1.98).

The obtained results are similar to that of Abouel-Enain (2002) summarized that under Alexandria local condition, the average honey yield per colony was 3.5, 6.2 and $8.5 \mathrm{~kg} /$ colony for the Egyptian Carniolan and the hybrid, respectively, most of honey harvested was during clover season in June and during cotton season in September. Helal et al. (2003) stated that the highest amount of honey throughout the three different Blooming seasons of citrus, clover and cotton was obtained from colonies moved to food source- rich area, the largest yield of honey was collected during may (clover season), followed by April (citrus blooming period). Dukku (2003) reported that, in Nigeria, beekeepers obtain large crops of honey during a brief period from September to October. Serag EI-Dein (2004) mentioned that, the highest mean of honey yield in Biala, Kafr el sheikh region, was obtained during cotton nectar flow. Abd El-Rahman (2004) stated that, in Assuit region the largest average honey yield $(8.61 \mathrm{~kg} /$ colony) was obtained from cotton plants, followed by clover (3.96 kg/colony), then medical plants (3.08 kg/colony). Taha (2006) reported that, at Kafr Elsheik region the highest mean honey yield was (3.10\&3.09 $\mathrm{kg} /$ colony) recorded in two years. Abd El-Hady (2007) reported that the highest rate of stored honey was during spring season $(31.49 \%)$ followed by summer, autumn and winter recorded 29.16, 17.45 and $5.43 \%$, respectively. El-barbary (2007) found that the maximum amount of stored honey was recorded during may, 25 while the minimum amount was at June 15, after honey extraction, the highest rate of stored honey was registered during spring season $(31.49 \%$ of the total stored honey), followed by summer $(29.16 \%)$ then autumn , ( $17.45 \%)$ and winter $(5.43 \%)$ seasons.

\section{REFERENCES}

Abd El Hady, N.M. (2007). Studies on some activities of honeybee colonies under the environmental conditions of Damietta region. M. Sc. Thesis. Fac. Agric. Cairo. Univ. Egypt, 191 pp.

Abd El Rahamn, M.F. (2004). Comparative studies between the characters of some races and hybrids of honeybee in Assuit region. Upper Egypt. Ph .D. Thesis . Fac. Agric. Assuit Univ., 373 pp.

Abou El-Enain, H.T. (2000). Factors affecting the quality of queen honeybee. Ph. D. Thesis. Fac. Ain shams Univ.,117pp.

Abou El Enean, A.L. (2002). Genetic studies on the honeybee. Ph.D. Thesis, Fac., Agric, Alex, Univ., 197 pp.

Bankova, V. S., S.S. Popov and N. L. Marekov (2007). Comparative study between honeybees on propolis. $J$. Natural Products, $46: 471-474$.

CoStat 6.400. (2008). Statistical CoHort Software program , Copyright (c) 19982008 CoHort Software 798 Lighthouse Ave. PMB 320 Monterey CA , 93940 USA .

Dimou, M. and A. Thrasyvoulou (2007). A comparison of three methods for assessing the relative abundance of 
pollen resources collected by honeybee colonies. J. of Apic. Res. 46(3): 144-148

Dukku, U.H. (2003). Acacia ataxacantha, a nectar plant for honeybees between two dearth periods in the Sudan savanna of northern Bigeria. Bee World, 884 (1): 32-33.

El-barbary, Nora Abelhady (2007). Studies on some activities of honeybee colonies under the environmental conditions of Damitta region. M. Sc. Thesis, Fac. Agric, Cairo Univ. Egypt .

Farrar, C.L. (1968). Productive management of honeybee colonies Amer. Bee. J. 108 (3):95-97.

Frasnay, J. (1962). A new instrument for brood measurements in a honeybee colony . American Bee Journal, 111(1): 20-21.

Funari, S.R.C., H.C. Rocha, J.M. Sforcin, P.R. Curi, A.R. Funari and R.O. Orsi (2003). Effects of pollen collection on colony development and in the bromatological composition Apis mellifera L. pupae. Archivos Latinoamericanos de Produccion Animal. 11 (2). 80-86.

Helal, R.M., T.N. El-dakhakhni, M.R. Shawer and E.A. Taha (2003). Effect of moving the apiaries on activity of honeybee colonies. 1-flight activity, gathering of nectar and sugar concentration contents and honey. J. Agric. Res. Tanta Univ., 29 (2):268-282.

Hussein, M.H. (1983). Relationship between number of extracted combs, brood rearing and honey production of bee colonies in Assuit area. Assuit J . Agric. Sci. 14 (4):171-182.

Malaspina, O. and A. J. Patenate (1995). Foraging behaviour of Africanized, Italian and Carniolan bees. Rev. Brazil. Biol., 55(I): 157-162.
Mansour, H.A., F.Sh. Serag Eldin and A. M. Khater (2008). Comparative study on some activities and products between hybrids of Carniolan and Italian honeybee. J. Agric. Sci. Mansoura Univ. 33 (12) : 8889 - 8898.

Polishchuk, V.P. (1984). Pollen gathering during a honey flow, Pchelovodstvo, 11. 12-13.

Rashad, S.E., I. Mohamed and S.M. ElShakaa (1979). Behavior of honeybee worker on major pollen sources in Giza region. Annals of Agric. Sci. Moshtohor, vol. 12:82-91.

Richard, L., I. I. Hellmich and W.C. Rothenbuhler (1986). Pollen hoarding and use by high and low pollen hoarding honeybees during the course of brood rearing. J. Apic. Res.,25(I).3034.

Serag EI Din, F.S. (2004). Comparative study on some products of Italian and Carniolan honeybee hybrids at Kafr El-Sheikh governorate . J. Agric. Sc. Mansoura Univ., (1): 409-416.

Shawer, M.B. (1980). Studies on both Carniolan and Egyptian honeybee and their crosses. J. Agric. Res. Tanta Univ., 6(2): 333-337.

Shawer, M.B. (1987). Major pollen sources in Kafr El-Sheikh, Egypt and the effect of the pollen supply on broad area and honey yield. J. of Apic. Res., 26(1): 43-46.

Sugden, M.T. and B. Furgala (1982). Evaluation of six commercial honey bee (A. mellifera L.) stocks used in Minnesota part 3 productivity. Am. Bee J., 122 (4): 283-286.

Taha, A.A. (2006). Comparative studies on some secondary products in different races. Ph. D. Thesis Fac. Agric., Mansoura Univ, Egypt, 186 pp. 


\section{دراسات مقارنة على بعض الانشطة النحلية بمحافظة الشرقية}

رضا عليوه سند(1) ، فتحى السعيد السنطيل(2) ، حمزة السبد الثرقاوى(2) ، رضا ثابت ابراهيم(1) (1) قسم بحوث النحل - معهز بحوث وقاية النباتات (2) كلية التكنولوجيا والتنمية - جامعة الزقازيق

الملخص العربى

أجريت هذه الدراسة فى ثلاث مراكز بمحافظة الثرقية لدراسة بعض أنثطة طوائف نحل العسل وذلك خلال عاميين متتاليين 2014 ، 2015 ـ حيث أختير منحل خاص فى كل مركز يتكون من 21 خلية نحل كرنيولى هجين أول وذلك

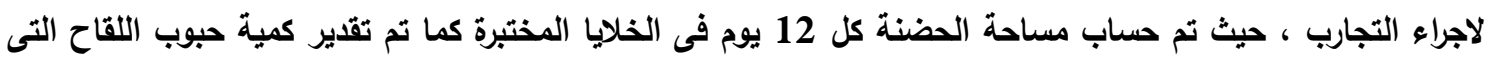
جمعتها الثغالات عن طريق تركيب مصائد بمداخل الخلايا المختبرة ـ كما تم تقدير انتاج العسل على مدار مواسم الموالح والبرسيم والقطن .

أظهرت نتائج الدراسة ان متوسط مساحة الحضنة 126.6 ، 137.4 ، 145.8 بوصة مربعة / خلية فى العام الاول فى مراكز الزقازيق وديرب نجم ويلبيس على التوالى ، بينما كانت فى العام الثانى 131.7 ، 131.1 141. ، 141.

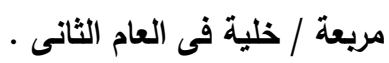
كما أوضحت نتائج الدراسة أن متوسط وزن حبوب اللقاح 120.55 ، 111.26 ، 11 ، 84.48 جرام لكل مصيدة في العام

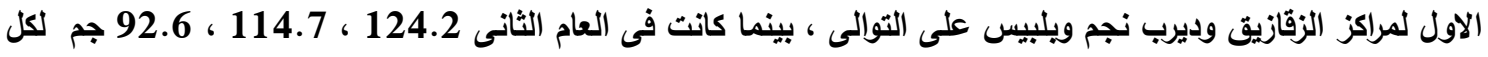
مصيدة فى العام الثانى 2015 وكان هناك فرق معنوى بين المراكز واعطى مركز الزقازيق العلى التئ النتائج.

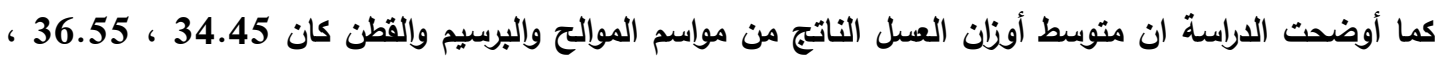

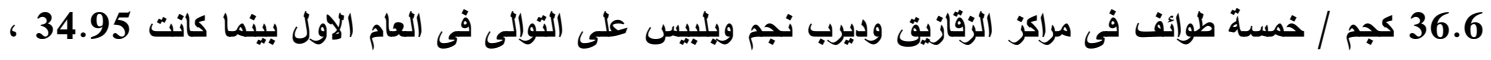
37.43 ، 37.1 كجم / خمسة طوائف فى مراكز الزقازيق وديرب نجم ويلبيس على التوالى فى العام الثانى دون فروق 
